\title{
Spontaneous Pyogenic Spinal Epidural Abscess
}

\author{
Spontan Spinal Epidural Abse
}

\author{
Tunc OKTENOGLU ${ }^{1}$, Mehdi SASANI ${ }^{1}$, Birsen CETIN ${ }^{2}$, Hakan BOZKUS ${ }^{1}$, Omur ERCELEN ${ }^{3}$, Metin VURAL ${ }^{4}$, \\ Ali Fahir OZER ${ }^{1}$, Ali Cetin SARIOGLU ${ }^{1}$ \\ ${ }_{1}^{1}$ American Hospital, Department of Neurosurgery, Istanbul, Turkey \\ ${ }^{2}$ American Hospital, Department of Infectious Diseases and Clinical Microbiology, Istanbul, Turkey \\ ${ }^{3}$ American Hospital, Department of Anesthesiology and Pain Management, Istanbul, Turkey \\ ${ }^{4}$ American Hospital, Department of Radiology, Istanbul, Turkey
}

Correspondence address: Tunc OKTENOGLU / E-mail: tuncoktenoglu@gmail.com

\begin{abstract}
AIM: Spontaneous pyogenic spinal epidural abscess (SEA) is a rare condition but might be devastating and fatal. Traditional treatment is surgical decompression and antibiotics. A retrospective study was designed to assess the effect of clinical findings and treatment methods on the outcome.

MATERIAL and METHODS: 14 patients were reviewed (10 male, 4 female, mean age 59.14). Six dorsal, seven ventral and one dorsal with ventral SEA were observed. SEA found in thoracal (5), lumbar (4), cervical (3) regions. One patient showed both cervical and thoracal and one patient showed cervical, thoracal and lumbar involvement. All patients received minimum 3 weeks of I.V., followed by minimum 3 weeks of oral antibiotics. All patients complained of spinal pain. Ten patients presented with fever. Neurological deficit was observed in 9 cases.

RESULTS: A total of 22 interventions was performed. Instrumentation was applied in 5 cases. Full recovery was achieved in 7 patients, significant improvement was observed in 5 patients. The neurological findings did not change in one patient. One mortality and one morbidity were observed.
\end{abstract}

CONCLUSION: Spontaneous SEA is a rare disease but might result in catastrophic neurological deficits and fatal even with prompt treatment. Therefore, one should always keep SEA in mind if a patient presents with fever, vague and spinal pain.

KEYWORDS: Spinal infection, Spinal epidural abscess, Spondylodiscitis, Spinal instrumentation, Antibiotics, Spinal surgery

ÖZ

AMAÇ: Spinal epidural abseler spinal cerrahi pratiğinin nadir problemlerindendir. İnsidansı yaklaşık 1,2/10.000'dir son yıllarda modern tanı yöntemlerinin daha yaygın kullanımı ile birlikte tanı koymak kolaylaşmışır. Bu çalışmada kliniğimizde spontan epidural abse nedeniyle tedavi edilen hastalar retrospektif olarak incelenmiştir.

YÖNTEM ve GEREÇ: Toplam 14 hasta spontan spinal abse tanısıyla tedavi edilmiştir. 10 hasta erkek ve 4 hasta bayandır. Ortalama yaş 59,14 . 6 hastada dorsal, 7 hastada ventral, 1 hastada hem dorsal hem ventral yerleşimli abse saptanmıştır. 5 hastada torakal, 4 hastada lomber, 3 hastada servikal, 1 hastada servikal ve lomber, 1 hastada ise tüm spinal kolonda tutulum görülmüştür. Tüm hastalar minimum 3 hafta IV ve sonrasında minimum 3 hafta oral antibiyotik tedavisi aldı. Toplam 9 hastada nörolojik muayenelerinde çeşitli bulgular saptandı. Tüm hastalarda spinal ağrı ve 10 hastada ateş yakınması saptandı.

BULGULAR: Toplam 22 girişim yapıldı 5 hastaya enstrumantasyon uygulandı. En sık saptanan mikroorganizma Staphylococcus auerus'du. Tam düzelme 7 hastada görüldü, 5 hastada belirgin düzelme sağlandı. 1 hastada nörolojik fonksiyonlarda iyileşme olmadı. 1 mortalite ve 1 morbidite görüldü.

SONUÇ: Spontan spinal epidural abse ağır morbidite ve hatta mortalite ile sonuçlanabilecek ciddi bir problemdir. Spinal ağrı ve ateş yakınması ile başvuran hastalarda mutlaka akılda tutulması gereken bir hastalıktır. Erken tanı ve müdahale hayat kurtarıcıdır.

ANAHTAR SÖZCÜKLER: Spinal enfeksiyon, Spinal epidural abse, Spondilodiskitis, Spinal enstrumentasyon

\section{INTRODUCTION}

Spontaneous spinal epidural abscess (SEA) is an uncommon problem that accounts for 0.2 to 2 per 10.000 hospital admissions $(2,15)$. Recent studies have reported higher rates $(4,11,34)$. Ptaszynski et al found 0.88 cases per 100,000 person-years, in the first report of the population-based incidence of SEA (32). SEA represents a spinal emergency condition and a potentially life-threatening disease that can cause severe neurological deficits by either; a) compression of abscess onto the spinal cord or nerve roots or $b$ ) ischemia due to compression. The neurological deficits can be as severe as paralysis.

SEA is usually localized in the thoracal region and closely followed by lumbar involvement. Cervical involvement occurs in less than $15 \%$ of epidural abscess cases $(7,12,16)$. 
Dorsal location of abscess is observed in almost two thirds of cases probably due to of heametogenous spread, but might be contiguous spread from a paravertebral infection. On the other hand, ventrally located abscess is rare and usually associated with spondylitis and/or discitis (12).

The most common agents responsible for SEA are grampositive microorganisms (80\%) with staphylococcus aureus the most cultured agent. This is followed by gram-negative and anaerobe microorganisms (16).

The study presented here reports the retrospective analysis of the patients with spontaneous SEA since 1997.

\section{MATERIAL and METHODS}

We retrospectively reviewed the records and radiologic studies of the patients who were treated for SEA, between January 1997 and October 2009. A total of 32 patients were diagnosed as spinal epidural abscess. 18 patients are eliminated from the study due to they had an overt iatrogenic cause in their close medical history to develop spinal abscess. The remaining 14 patients included to the study.

The four of the patients were female and ten patients were male. The mean age was 59.14 and age range was (49-74).

The demographic and clinical data of the patients is shown on Table I and II.

Six patients (patients no: 1, 2, 4, 8, 9, 11) showed dorsally located SEA (42.9\%) and seven patients (patients no: 3, 5, 6, $7,10,12,14)$ showed ventrally located SEA (50.0\%). In one patient (patient no: 13) both ventral (cervical) and dorsal (thoracal) SEA (7.1\%) were observed (Figure 1 and Table I).
Five patients (patients no: 1, 2, 4, 7, 12) showed thoracal involvement (35.8\%), four patients (patients no: 6, 9, 10, 11) showed lumbar involvement $(28.6 \%)$, three patients (patients no: $3,5,8$ ) showed cervical involvement (21.4\%), one patient (patient no: 13) showed both cervical and thoracal involvement (7.1\%) (Figure 1, Table I). In one patient (patient no: 14), the involvement of all spinal regions (cervical, thoracal and lumbar) was observed (7.1\%)

A total of 8 patients (57.1\%, patients no: $2,3,5,6,7,12,13$, 14) showed spondylodiscitis in addition to spinal epidural abscess (Table I). Only patient no: 2 showed dorsal SEA with spondylodiscitis (Figure 2, Table I).

In 12 patients the initial treatment method was surgical decompression under general anesthesia (Table II). In one patient (patient no: 11) the drainage of the abscess was performed with 18 no spinal gauge under fluoroscopy. In one patient (patient no: 6) antibiotic therapy was applied as an initial treatment method after CT-guided biopsy. However, in the 3 rd week of I.V. antibiotic therapy the patient was operated due to onset of severe neurological deficit (Table I).

Antibiotic therapy was applied according to microbiology culture and antibiogram studies. All patients received minimum 3 weeks of I.V. antibiotics (mean: 6.57) therapy and followed by oral antibiotics for minimum 3 weeks for 12 patients (mean:4.33) (Table III). The application of metallic instrumentation to the spine (totally 5 patients, Table II) was extended the antibiotic treatment to minimum 6 weeks I.V. (mean: 11.0; for 5 patients) and minimum 4 weeks oral (mean:4.0; for 3 patients) (Table III). The antibiotic treatment
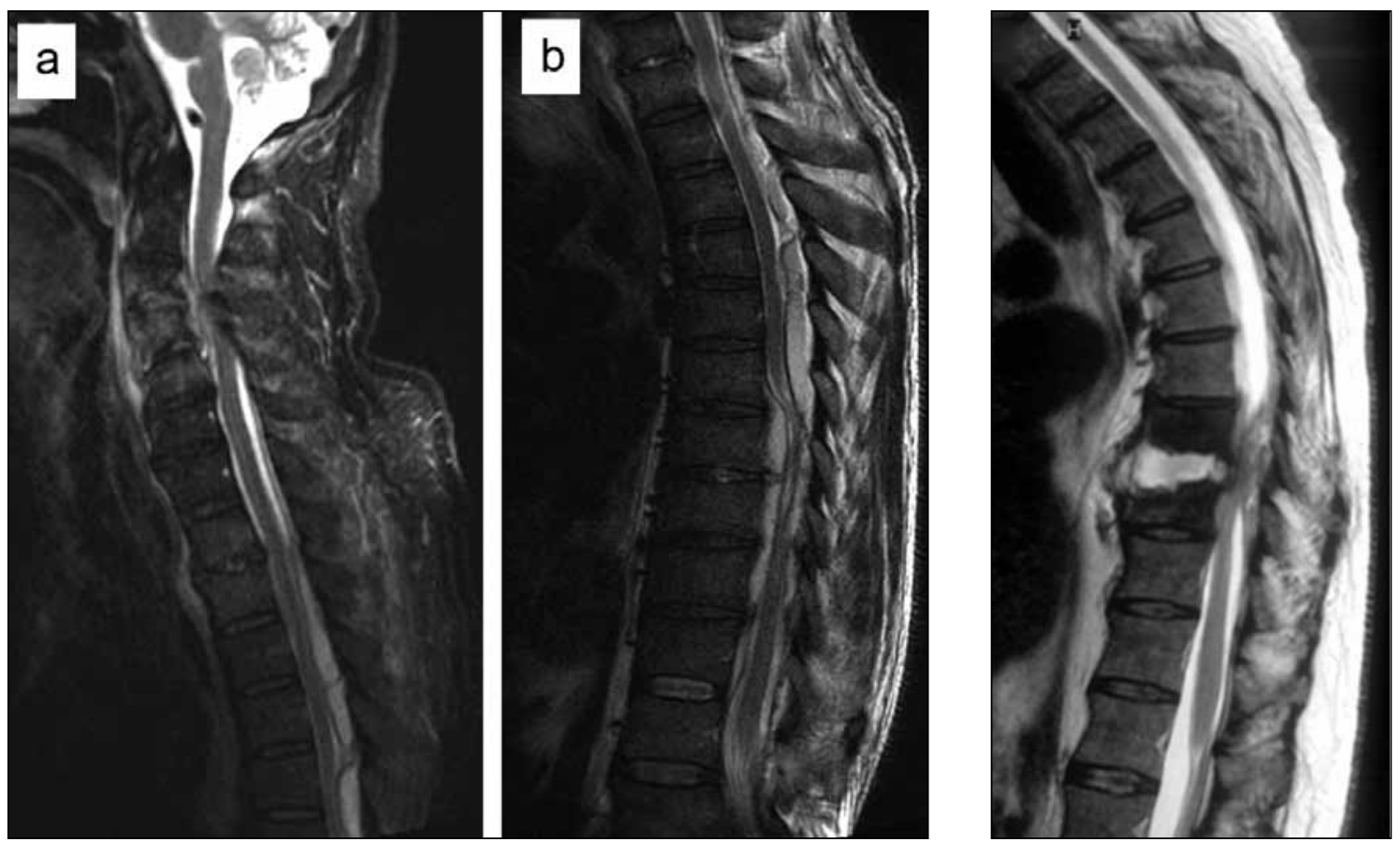

Figure 2: Patient no; 2 , sagittal T2-weighted image shows spondylodiscitis with SEA at T8-9 levels and dorsal epidural abscess between T7-9 levels.

Figure 1: Patient no;13, sagittalT2 -weighted image A) shows spondylodiscitis with SEA at C3-5 level. B) T4-7 dorsal abscess. 
Table I: Demographic and Clinical Data of the Patients

\begin{tabular}{|c|c|c|c|c|c|c|c|}
\hline $\begin{array}{l}\text { Patient } \\
\text { No }\end{array}$ & Age & Sex & Complaints & $\begin{array}{c}\text { Neurologic } \\
\text { Examination } \\
\text { ASIA* }\end{array}$ & $\begin{array}{l}\text { Medical } \\
\text { History }\end{array}$ & $\begin{array}{l}\text { MR } \\
\text { Findings }\end{array}$ & $\begin{array}{l}\text { Time to } \\
\text { Diagnosis } \\
\text { (Day) }\end{array}$ \\
\hline 1 & 72 & M & $\begin{array}{c}\text { Back pain } \\
\text { Subfebrile fever } \\
\text { Difficulty in walking }\end{array}$ & 84 & DM & T8-11 Dorsal abscess & 9 \\
\hline 2 & 60 & M & $\begin{array}{c}\text { Back pain } \\
\text { Subfebrile fever } \\
\text { Difficulty in walking }\end{array}$ & 78 & NA & $\begin{array}{l}\text { T7-9 Dorsal abscess and } \\
\text { T8,9 Spondylodiscitis }\end{array}$ & 6 \\
\hline 3 & 51 & M & $\begin{array}{l}\text { Neck pain } \\
\text { Fever }\end{array}$ & 100 & Chronic renal failure & $\begin{array}{l}\text { C4-5 Ventral abscess } \\
\text { and C4,5 Spondylodiscitis }\end{array}$ & 2 \\
\hline 4 & 65 & $\mathrm{~F}$ & $\begin{array}{c}\text { Back pain } \\
\text { Fever } \\
\text { Difficulty in walking }\end{array}$ & 100 & DM & T9-10 Dorsal abscess & 3 \\
\hline 5 & 75 & M & $\begin{array}{l}\text { Difficulty in breathing } \\
\text { Fever } \\
\text { Motor weakness at } \\
\text { extremities }\end{array}$ & 30 & DM & $\begin{array}{l}\text { C3-6 Ventral abscess } \\
\text { C4-5 Spondylodiscitis } \\
\text { C3-6 Cervical stenosis }\end{array}$ & 12 \\
\hline 6 & 57 & M & $\begin{array}{l}\text { Low back pain } \\
\text { Subfebrile fever } \\
\text { Difficulty in walking }\end{array}$ & 95 & NA & $\begin{array}{l}\text { L3-4 Spondylodiscitis } \\
\text { and Ventral abscess }\end{array}$ & 7 \\
\hline 7 & 49 & M & $\begin{array}{c}\text { Back pain } \\
\text { Subfebrile fever } \\
\text { Difficulty in walking }\end{array}$ & 78 & $\begin{array}{c}\text { Pancreas CA: } \\
\text { Surgery ( } 8 \text { months } \\
\text { ago) } \\
\text { Chemotherapy and } \\
\text { radiotherapy (6 } \\
\text { months ago) }\end{array}$ & $\begin{array}{l}\text { T3-4 Spondylodiscitis } \\
\text { and Ventral abscess }\end{array}$ & 11 \\
\hline 8 & 72 & $\mathrm{~F}$ & $\begin{array}{c}\text { Neck pain } \\
\text { Weakness at left arm }\end{array}$ & 96 & DM & $\begin{array}{l}\text { C6-7 Dorsal } \\
\text { abscess }\end{array}$ & 19 \\
\hline 9 & 44 & M & $\begin{array}{l}\text { Back pain } \\
\text { Fever }\end{array}$ & 100 & DM & $\begin{array}{l}\text { L5 dorsal } \\
\text { abscess }\end{array}$ & 2 \\
\hline 10 & 67 & M & $\begin{array}{l}\text { Low back and } \\
\text { Right leg pain }\end{array}$ & 88 & DM & $\begin{array}{l}\text { L1-2ventral } \\
\text { abscesses }\end{array}$ & 9 \\
\hline 11 & 68 & $\mathrm{~F}$ & $\begin{array}{l}\text { Pain at low back } \\
\text { and both legs }\end{array}$ & 70 & DM & $\begin{array}{l}\text { L2-3 dorsal } \\
\text { abscess }\end{array}$ & 4 \\
\hline 12 & 42 & M & $\begin{array}{c}\text { Back pain } \\
\text { Difficulty in walking }\end{array}$ & 70 & DM & $\begin{array}{l}\text { T8-T9 ventral abscess } \\
\text { T8-9 spondylodiscitis }\end{array}$ & 8 \\
\hline 13 & 44 & M & $\begin{array}{c}\text { Back pain } \\
\text { Muscle weakness } \\
\text { at arms and legs nausea }\end{array}$ & 74 & $\begin{array}{l}\text { Ischemic heart } \\
\text { disease }\end{array}$ & $\begin{array}{l}\text { C3-C5 ventral abscess, } \\
\text { C4-5 Spondylodiscitis } \\
\text { Cervical canal stenosis } \\
\text { T4-7 dorsal abscess }\end{array}$ & 37 \\
\hline 14 & 62 & $F$ & $\begin{array}{c}\text { Back pain } \\
\text { Muscle weakness } \\
\text { at arms and legs nausea } \\
\text { Difficulty in walking }\end{array}$ & 80 & $\begin{array}{l}\text { Ischemic heart } \\
\text { disease } \\
\text { DM }\end{array}$ & $\begin{array}{l}\text { Cervical, thoracal abscess } \\
\text { lumbar vertical abscess } \\
\text { L5-S1spondylodiscitis }\end{array}$ & 26 \\
\hline
\end{tabular}

- ASIA: American Spinal Injury Association 
period was determined depending on clinical findings and blood analysis (erythrocyte sedimentation rate (ESR), Creactive protein (CRP)). Improvement in clinical findings and decrease by half of the infection markers (ESR, CRP) is accepted to change I.V. treatment to oral treatment (35).

The patients who showed neurological deficit was placed on a physical therapy and rehabilitation program as soon as possible following surgery.

All patients were followed-up for a minimum of 16 months (mean: 28.0) (Table II).

\section{RESULTS}

A total of 22 interventions (including CT-guided biopsy and drainage with fluoroscopy) was performed to 14 patients (Table II). Three operations were performed on patient no:5 in three different sessions. Three operations were performed on patient no: 13 in two different sessions. Two operations were performed on patients no: 2 and 3 in same sessions and two interventions were performed on patients no: 6 and 11 in different sessions. A single procedure was performed on eight patients (patients no: $1,4,7,8,9,10,12$ and 14). In 5 patients (patients no: 2, 3, 5, 7, 13), metallic instrumentation was

Table II: Clinical Data of the Patients

\begin{tabular}{|c|c|c|c|c|c|}
\hline $\begin{array}{l}\text { Patient } \\
\text { No }\end{array}$ & Surge & $\begin{array}{r}\text { (Intervention) } \\
2^{\text {nd }}\end{array}$ & $3^{\text {rd }}$ & $\begin{array}{l}\text { Follow-up } \\
\text { (months) }\end{array}$ & $\begin{array}{l}\text { Outcome } \\
\text { ASIA* }\end{array}$ \\
\hline 1 & $\begin{array}{l}\text { T8-T11 total laminectomies and } \\
\text { abscess drainage }\end{array}$ & & & 35 & 100 \\
\hline 2 & $\begin{array}{l}\text { A)T8-9 corpectomies and cage } \\
\text { insertion } \\
\text { B)T8-9 total laminectomies, abscess } \\
\text { drainage and } T 6,7,10,11 \text { posterior } \\
\text { instrumentation }\end{array}$ & & & 34 & 100 \\
\hline 3 & $\begin{array}{l}\text { A)C } 4-5 \text { corpectomies, abscess drainage } \\
\text { and cage insertion } \\
\text { B)C } 3-6 \text { posterior lateral mass fixation }\end{array}$ & & & 28 & 100 \\
\hline 4 & $\begin{array}{l}\text { T9-10 total laminectomies and abscess } \\
\text { drainage }\end{array}$ & & & 30 & 100 \\
\hline 5 & C3-6 total laminectomies and biopsy & $\begin{array}{l}\text { C } 4-5 \text { corpectomies, } \\
\text { abscess drainage and cage } \\
\text { insertion }\end{array}$ & $\begin{array}{l}\text { C0-7 posterior } \\
\text { sublaminar wire } \\
\text { fixation }\end{array}$ & 16 & Exitus \\
\hline 6 & CT guided transpedicular biopsy & $\begin{array}{l}\text { L4 left hemilanotomy and } \\
\text { abscess drainage }\end{array}$ & & 36 & 98 \\
\hline 7 & $\begin{array}{l}\text { T3-4 corpectomies, abscess drainage, } \\
\text { cage insertion and T2-5 anterior plate } \\
\text { fixation }\end{array}$ & & & 38 & 90 \\
\hline 8 & $\begin{array}{l}\text { C6-7 left hemilaminectomy and } \\
\text { abscess drainage }\end{array}$ & & & 40 & 100 \\
\hline 9 & $\begin{array}{l}\text { L5 left hemilaminotomy and abscess } \\
\text { drainage }\end{array}$ & & & 22 & 100 \\
\hline 10 & $\begin{array}{l}\text { L1 right hemilaminectomy and abscess } \\
\text { drainage }\end{array}$ & & & 21 & 100 \\
\hline 11 & Abscess drainage with fluoroscopy & $\begin{array}{l}\text { Abscess drainage with } \\
\text { fluoroscopy }\end{array}$ & & 22 & 94 \\
\hline 12 & $\begin{array}{l}\text { T8-9 right hemilaminectomies and } \\
\text { abscess drainage }\end{array}$ & & & 20 & 90 \\
\hline 13 & $\begin{array}{l}\text { C3-5 laminectomies, abscess drainage } \\
\text { and } \\
\text { C3-5 fixation posterior lateral mass }\end{array}$ & $\begin{array}{l}\text { C4-5 Anterior } \\
\text { Microdiscectomy and } \\
\text { abscess drainage }\end{array}$ & & 22 & 76 \\
\hline 14 & $\begin{array}{l}\text { L4 right hemilaminectomy and abscess } \\
\text { drainage }\end{array}$ & & & 28 & 90 \\
\hline
\end{tabular}

${ }^{*}$ ASIA: American Spinal Injury Association 
Table III: Clinical Data of the Patients

\begin{tabular}{|c|c|c|c|c|c|c|c|}
\hline \multirow{2}{*}{$\begin{array}{l}\text { Patient } \\
\text { No }\end{array}$} & \multirow{2}{*}{ Fever } & \multirow{2}{*}{ Leukocyte } & \multirow{2}{*}{$\begin{array}{c}\text { ESR } \\
\text { (1 hour) }\end{array}$} & \multirow{2}{*}{ CRP } & \multirow{2}{*}{ Microorganism } & \multicolumn{2}{|c|}{$\begin{array}{c}\text { Antibiotic Treatment } \\
\text { (weeks) }\end{array}$} \\
\hline & & & & & & I.V. & Oral \\
\hline 1 & $(+)$ & 16.5 & 78 & 181 & Staphylococcus xylosus & 3 & 3 \\
\hline 2 & $(+)$ & 9.1 & 80 & 150 & Staphylococcus aureus & 6 & 4 \\
\hline 3 & $(+)$ & 14.3 & 36 & 23 & MRSA & 6 & 4 \\
\hline 4 & $(-)$ & 11.4 & 30 & 18 & Staphylococcus aureus & 3 & 4 \\
\hline 5 & $(+)$ & 7.8 & 96 & 344 & MRSA & 25 & - \\
\hline 6 & $(+)$ & 15.8 & 48 & 123 & Staphylococcus aureus & 5 & 6 \\
\hline 7 & $(-)$ & 10.2 & 28 & 53 & MRSA & 6 & 4 \\
\hline 8 & $(+)$ & 13.2 & 70 & 115 & Streptococcus oralis & 3 & 3 \\
\hline 9 & $(-)$ & 12.2 & 32 & 28 & Staphylococcus aureus & 3 & 3 \\
\hline 10 & $(-)$ & 12.2 & 58 & 46 & Staphylococcus aureus & 3 & 3 \\
\hline 11 & $(+)$ & 26.8 & 74 & 139 & Staphylococcus aureus & 4 & 6 \\
\hline 12 & $(+)$ & 13.0 & 86 & 288 & Staphylococcus aureus & 4 & 4 \\
\hline 13 & $(+)$ & 12.4 & 26 & 59 & Staphylococcus aureus & 12 & - \\
\hline 14 & $(+)$ & 16.4 & 110 & 220 & Staphylococcus aureus & 9 & 8 \\
\hline Mean & & 16.40 & 60.85 & 127.64 & & 6.57 & $4.33^{*}$ \\
\hline
\end{tabular}

*12 patients

applied to stabilize the spinal column after decompression procedures (Figure 2).

All patients showed signs of infection (elevated ESR rate and CRP levels) in blood samples (Table III). The mean ESR was 60.86 and mean CRP was 127.64. Four patients (patients no: $4,7,9$, and 10) were admitted to the outpatient clinic with complaints of spinal pain and radicular symptoms, and there was no fever.

Time to diagnosis was 2-31 days (mean: 11.07) (Table I). Twelve patients showed improvement following surgical intervention and appropriate antibiotic therapy. Full recovery achieved in 7 patients (Table II). In one patient (patient no: 13) the neurologic status did not change; only pain relief was achieved. On the other hand, one patient (patient no: 5) died even to multiple surgeries and aggressive antibiotic therapy for 6 months. In one patient (patient no: 13), severe morbidities (acute renal failure, atrial fibrillation, pneumonia, urinary tract infection) were observed in the second postoperative period. The antibiotic treatment for this patient was 12 weeks I.V. both for SEA and developed morbidities. The oral antibiotic after I.V. treatment was given for the morbidities (Table III).

\section{DISCUSSION}

Spinal epidural abscess is first reported by Morgagni in 1796 $(19,33)$. In 1948, Huesner described the clinical findings, treatment and outcome of SEA (15). The SEA following spinal surgery or spinal intervention (such as pain procedures) is a well known complication. Recently Grewal et al reported a review article to minimize the risk of anesthetic practice (13).

Most of the patients with SEA is associated with an disease (such as Diabetus Mellitus (DM), AIDS, Chronic renal failure, cancer, cirrhosis) or condition that suppress the immune system (e.g. alcoholism, I.V. drug abuse, trauma).

D.M. is the most common disease as a factor in $18-54 \%$ of cases $(9,17,30)$. I.V. drug abuse $7-40 \%(1,10)$ and remote infections $7-44 \%(20,26)$ are the other common factors that associated with SEA.

Only $10-20 \%$ of patients have no predisposing factor $(31,38,40)$.

We observed similar findings; 9 patients (64.2\%) had DM, one patient had chronic renal failure and one patient had pancreas carcinoma. 
The presenting symptoms are mainly spinal pain and fever. The neurological deficit might develop in hours or even in months due to compressive effect of epidural abscess or ischemia. The exact mechanism of how an epidural abscess causes spinal cord damage is still unclear.

There is not always parallel findings with the size of spinal cord compression and clinical picture (28). Severe neurological deficit with intact subarachnoid space and severe cord compression without neurological deficit have both reported (6). We observed similar findings, for example patient no: 8 admitted with obstructed subarachnoid space and severe spinal cord compression in the MRI study (Figure 3). However, the neurological examination showed only monoparesis due to radiculopathy (Table I). On the other hand, patient no:12 was admitted with severe paraparesis but the MRI study showed intact subarachnoid space (Figure 4). Additionally, the recovery following surgery even in the patients with unobstructed subarachnoid space is slower compared to the patients with significant spinal cord compression due to tumor. Therefore, it is reasonable to explain the mechanism of the spinal cord dysfunction with ischemia due to compression of spinal arteries and/or thrombosis of leptomeningeal vessels (5).

The literature shows that most of the patients present with dorsal thoracal involvement. This is explained by this segment having a relatively larger epidural space and especially the size of Batson's epidural venous plexus is bigger compare to other spinal segments. Batson believed that the microorganism could spread via a valveless low pressure venous system. Therefore, it is thought that these anatomic features allow easy abscess formation $(4,38,41)$.

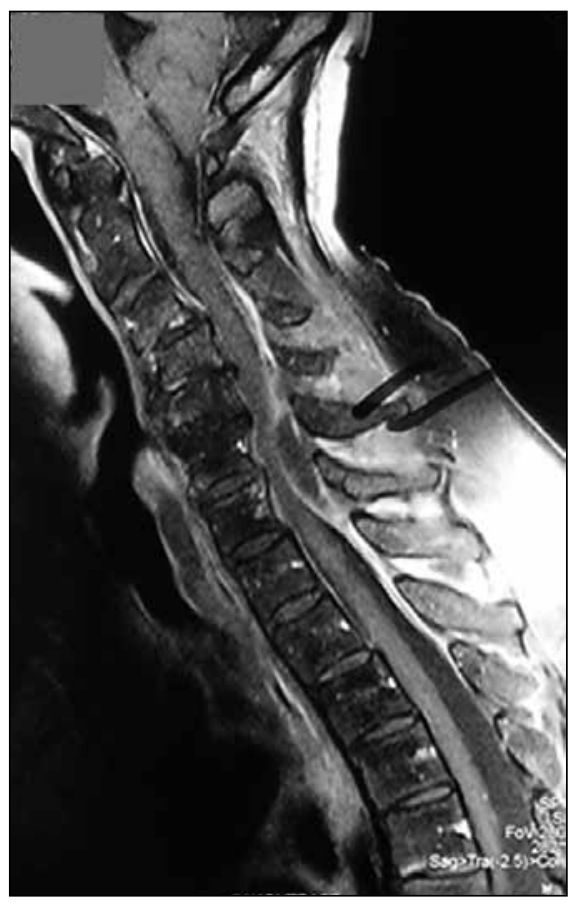

Figure 3: Patient no;8 Postcontrast sagittal T1 weighted image shows thick enhancement around nonenhancing collection of pus with severe cord compression.
On the other hand, Wiley and Trueta (41) showed the vascular anatomy of the spine. They reported that Batson's plexus was filled only under high pressure. However, arterial injections were performed easily. Therefore, the authors believed that the mechanism of infection is arterial. Today there is no clear mechanism to explain how the microorganisms metastasize to epidural space.

We observed that involvement of the thoracal region (totally 5 patients) is slightly more than the lumbar (totally 4 patients) or cervical region (totally 3 patients). Thoracal dorsal involvement was observed in only 3 patients (patients no; $1,2,4)$. This finding did not correlate with the literature. The small size of the patient population might be the reason. On the other hand the literature is mostly from the patients with secondary SEA. Data on spontaneous SEA is rare. Therefore, the demographic findings of spontaneous SEA might show differences from secondary SEA.

Early diagnosis significantly decreases the morbidity and mortality rates $(23,24,38)$.

Radiological studies are very important in diagnosis of SEA. Unfortunately, plain radiographs and $\mathrm{CT}$ have limited value. The SEA is easily demonstrated with a MR study. There are two basic patterns of enhancement of SEA described. The one with no liquid collection is only granulomatous tissues are observed as a solid mass with homogenous or heterogeneous contrast enhancement suggestive of phlegmonous stage (Figure 5). In the other form, there is a mass with circumferential contrast enhancement within liquid infection (29).

The treatment mostly depends on early surgical decompression and prolonged antibiotic therapy $(25,27,34,39,42)$. On

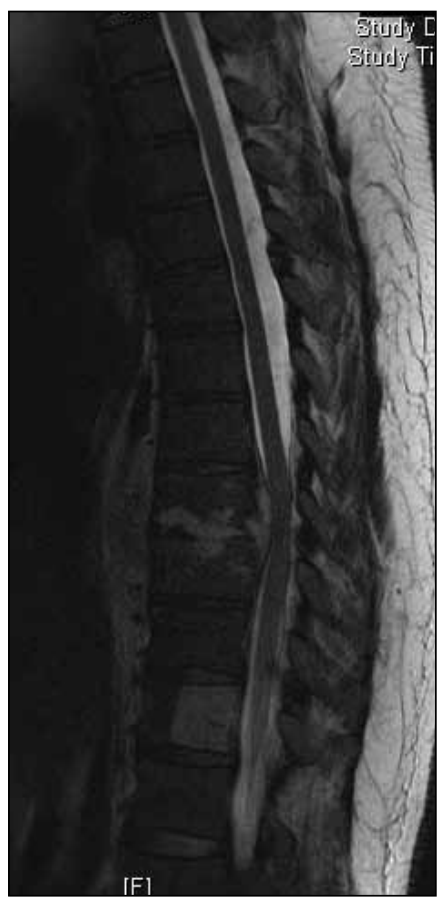

Figure 4: Patient no; 12 , T2 weighted sagittal MRI shows ventral abscess and spondylodiscitis at thoracal region, with unobstructed subarachnoid space 
the other hand, conservative therapy might be applied as the sole management in carefully selected patients $(20,22,30)$. Savage et al reported $83 \%$ good or excellent outcome with only medical treatment (36). However, it was concluded that $19 \%$ of the medically treated patients showed a severe neurological deterioration while under appropriate antibiotic therapy (22). Our observation supported this finding. Two patients (patients no 13 and 14) showed multiregion SEA involvement (Table I). Surgical intervention was carried out to only one spinal region in both patients (Table II). The treatment of the other affected spinal regions were achieved with antibiotic treatment. On the other hand, patient no: 10 first underwent CT biopsy and then appropriate antibiotic therapy was given. In the 3rd week of I.V. antibiotic therapy, the patient developed severe neurological deficit and immediate surgical intervention was carried out (Table II). Therefore, nonsurgical treatment might be applied to selected patients with close follow-up including neurological examination, control MR studies and laboratory findings.

The most interesting patient of this limited size of spontaneous SEA population was patient no: 11 . The patient was under conservative treatment for the last 3 months for low back pain due to severe degenerative changes. She developed a significant increase in low back pain in the last few days. The patient was referred to the pain department for an epidural pain management. No new MRI study was obtained prior to intervention. The diagnosis was achieved after abscess drainage through spinal needle at the epidural space. Therefore one should always keep SEA in mind, particularly in the geriatric population and a recent radiological study is critical before performing any spinal procedure.

The most common microorganism as a cause of spinal epidural abscess is Staphylococcus aureus. We have observed a similar finding as the etiologic agent was Staphylococcus aureus in 9 of $14(64.2 \%)$ patients. Interestingly we observed MethicillinResistant Staphylococcus Aureus (MRSA) in 3 patients. MRSA is an uncommon microorganism in patients with SEA. The common clinical finding of these 3 patients (patients no: 3 , $6,9)$ was a significant morbidity that suppressed the immune system, and having frequent I.V. therapies for their primary diseases (Table I). Therefore it is reasonable to believe that these patients were contaminated with MRSA in the health centers where they receive treatment.

The advances in radiology and treatment strategies significantly decreased the mortality of epidural abscess. In 1926 it was reported that the mortality is $81 \%$ (8). Between the years of 1954 and 1980 the mortality rates decreased from $34 \%$ to $16 \%$ (30). The recent studies reported less then $10 \%$ mortality $(1,10,14,18,37)$. However the larger studies that include only the nontuberculous patients showed little higher rates between 13 and 16\% (20). Cervical SEA has significantly higher mortality rate $38 \%$, compared to other spinal regions (43). In our study, the only mortality was observed in a patient with cervical SEA (patient no: 5, Table II).

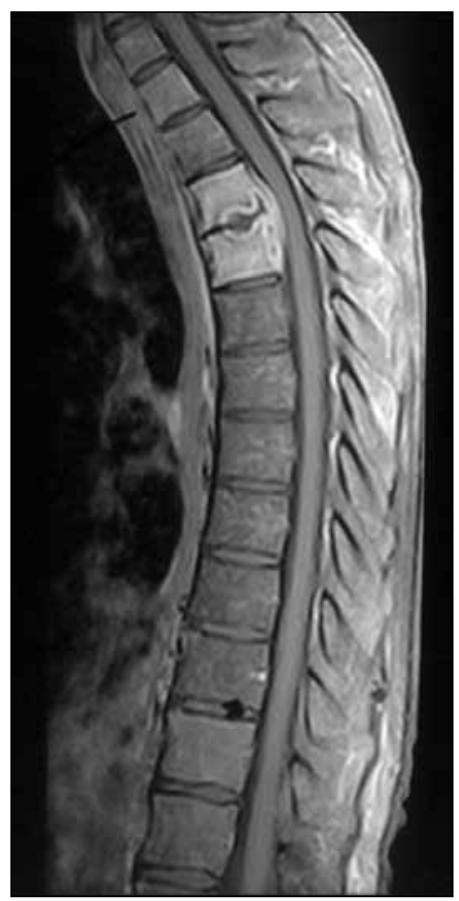

Figure 5: Patient no; 7 spondylodiscitis with anterior SEA postcontrast sagittal T1 weighted image shows homogenous enhancement suggestive of phlegmonous stage.

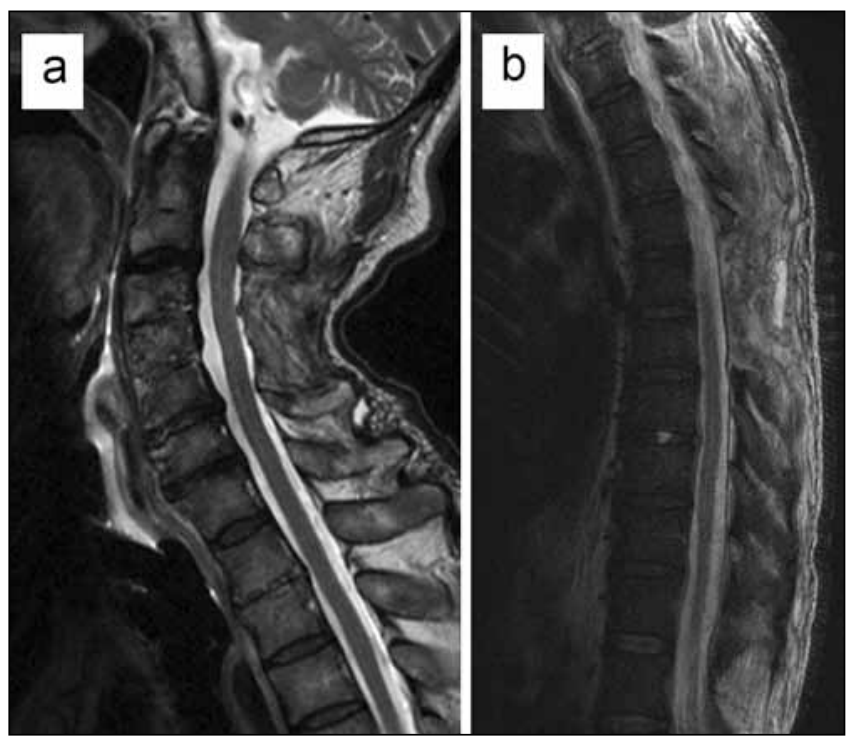

Figure 6: Patient no;13, sagittal T2 weighted A) cervical and B) thoracal images shows satisfactory radiologic outcome.

The application of foreign body (metallic instrumentation) to an infected site is usually not preferred. However it might be an inevitable in some conditions. We applied metallic instrumentation to 5 patients. Extensive removal of infected tissues was performed before instrumentation. The application of antibiotics were extended in all patients. Treatment of spontaneous SEA was achieved in 4 patients. However, the only mortality was observed in patient no:5 who received metallic instrumentation.

Khama et al (20) reported three factors associated with poor outcome: 1) age, 2) degree of spinal cord compression and 
3) duration of symptoms. Kumar and Hunter (21) concluded clinical suspicion, prompt investigation and immediate intervention are the most important factors in outcome of SEA.

We observed full recovery in seven patients (patients no: 1, $2,3,4,8,9,10)$ and four of them $(1,2,7,8)$ showed significant neurological deficit at presentation. In 4 patients (patients no: $6,11,12,14)$, an improvement in neurological deficits was achieved. The neurological findings did not change in one patient (patient no: 13) despite a long-term rehabilitation program.

Our experience showed that a delay in diagnosis and associated comorbidies can be fatal (patient no: 5) and might decrease the chance of full recovery of neurological deficits even with a satisfactory radiological outcome (patient no: 6, $7,11,12,13,14$ ) (Figure 6). Therefore, one should always keep SEA in mind if the patient presents with spinal pain with fever. Immediate spinal MR screening is mandatory in cases with additional neurological deficit.

\section{REFERENCES}

1. Akalan N, Ozgen T:Infection as a cause of spinal cord compression; A review of 36 spinal epidural abscess cases. Acta Neurochir (Wien)142:17-23, 2000

2. Baker AS, Ojemann RG, Swartz MN, Richardson EP Jr: Spinal epidural abscess. N Engl J Med 293:463-468, 1975

3. Batson OV: The function of the vertebral veins and their role in the spread of metastases. Ann Surg 112:138-149, 1940

4. Batson OV: The vertebral vein system. Am J Roentgenol Radium Ther Nucl Med 78:195-212, 1957

5. Breivik H: Safe perioperative spinal and epidural analgesia; Importance of drug combinations, segmental site of injection, training and monitoring. Acta Anaesthesiol Scand 39:869-871, 1995

6. Browder J, Meyers R: Pyogenic infections of the spinal epidural space; a consideration of the anatomic and physiologic pathology. Surgery 10:296-308, 1941

7. Currier BL, Eismont FJ: Infections of the spine. In: Rothman $\mathrm{RH}_{\text {, }}$ Siemone FA ed. The Spine. Philadelphia: WB Saunders, 1992: 1319-1380

8. Dandy WE: Abscesses and tumours in the spinal epidural space. Arch Surg 13: 477-494, 1926

9. Darouiche RO, Hamill RJ, Greenberg SB, Weathers SW: Bacterial spinal epidural abscess. Review of 43 cases and literature survey. Medicine (Baltimore) 71:369-385, 1992

10. Davis DP, Wold RM, Patel RJ, Tran AJ, Tokhi RN, Chan TC, Vilke GM: The clinical presentation and impact of diagnostic delays on emergency department patients with spinal epidural abscess. J Emerg Med 26:285-291, 2004

11. Espersen F, Frimodt-Møller N, Thamdrup Rosdahl V, Skinhøj $P$, Bentzon MW: Changing pattern of bone and joint infections due to Staphylococcus aureus; study of cases of bacteremia in Denmark, 1959-1988. Rev Infect Dis 13:347-358, 1991

12. Friedmand DP, Hills JR: Cervical epidural spinal infection; MR imaging characteristics. AJR Am J Roentgenol 163:699-704, 1994

13. Grewal S, Hocking G, Wildsmith JA: Epidural abscesses. British Journal of Anesthesia 96:292-302, 2006
14. Grieve JP, Ashwood N, O'Neill KS, Moore AJ: A retrospective study of surgical and conservative treatment for spinal extradural abscess. Eur Spine J 9:67-71, 2000

15. Heusner AP: Nontuberculous spinal epidural infections. N Engl J Med 239:845-847, 1948

16. Hitchon PW, Osenbach RK, Yuh WT, Menezes AH: Spinal infections. Clin Neurosurg 38:373-387, 1992

17. Hlavin ML, Kaminski HJ, Ross JS, Ganz E: Spinal epidural abscess; a ten-year perspective. Neurosurgery 27:177-184, 1990

18. Joshi SM, Hatfield RH, Martin J, Taylor W: Spinal epidural abscess; a diagnostic challenge. Br J Neurosurg 17:160-163, 2003

19. Khan SH, Hussain MS, Griebel RW, Hattingh S: Title comparison of primary and secondary spinal epidural abscesses; a retrospective analysis of 29 cases. Surg Neurol 59:28-33, 2003

20. Khanna RK, Malik GM, Rock JP, Rosenblum ML: Spinal epidural abscess; evaluation of factors influencing outcome. Neurosurgery 39: 958-964, 1996

21. Kumar K, Hunter G: Spinal epidural abscess. Neurocrit Care 2: 245-251, 2005

22. Leys D, Lesoin F, Viaud C, Pasquier F, Rousseaux M, Jomin M, Petit $\mathrm{H}$ : Decreased morbidity from acute bacterial spinal epidural abscesses using computed tomography and nonsurgical treatment in selected patients. Ann Neurol 17:350-355, 1985

23. Lohr M, Reithmeier T, Ernestus RI, Ebel H, Klug N: Spinal epidural abscess; prognostic factors and comparison of different surgical treatment strategies. Acta Neurochir 147:159-166, 2005

24. Lu CH, Chang WN, Lui CC, Lee PY, Chang HW: Adult spinal epidural abscess; clinical features and prognostic factors. Clin Neurol Neurosurg 104: 306-310, 2002

25. Mackenzie AR, Laing RB, Smith CC, Kaar GF, Smith FW: Spinal epidural abscess; the importance of early diagnosis and treatment. J Neurol Neurosurg Psychiatr;65: 209-212, 1998

26. Maslen DR, Jones SR, Crislip MA, Bracis R, Dworkin RJ, Flemming JE: Spinal epidural abscess. Optimizing patient care. Arch Intern Med 153:1713-1721, 1993

27. McGee-Collett $M$, Johnston IH: Spinal epidural abscess; presentation and treatment. A report of 21 cases. Med J Aust 155:14-17, 1991

28. McLaurin RL: Spinal suppuration. Clin Neurosurg 14: 314-336, 1966

29. Numaguchi Y, Rigamonti D, Rothman MI, Sato S, Mihara F, Sadato $\mathrm{N}$ : Spinal epidural abscess; evaluation with gadolinium-enhanced MR imaging. RadioGraphics 13: 545-59, 1993

30. Orlikowski C, Majedi PM, Keil AD: Bacterial contamination of epidural needles after multiple skin passes. $\mathrm{Br} J$ Anaesth 89: 922-924, 2002

31. Pereira CE, Lynch JC: Spinal epidural abscess; an analysis of 24 cases. Surg Neurol 63:26-29, 2005

32. Ptaszynski AF, Hooten WM, Huntoon MA: The incidence of spontaneous epidural abscess in Olmsted County from 1990 through 2000; a rare cause of spinal pain. Pain Med 8:338-343, 2007

33. Rea GL, McGregor JM, Miller CA, Miner ME: Surgical treatment of the spontaneous spinal epidural abscess. Surg Neurol 37: 274-279, 1992

34. Rigamonti D, Liem L, Sampath $P$, Knoller N, Namaguchi $Y$, Schreibman DL: Spinal epidural abscess; contemporary trends in etiology, evaluation, and management. Surg Neurol 52:189-196, 1999 
35. Sapico FL: Microbiology and antimicrobial therapy of spinal infections. Orthop Clin North Am 27: 9-13, 1996

36. Savage K, Holtom PD, Zalavras CG: Spinal epidural abscess; early clinical outcome in patients treated medically. Clin Orthop Relat Res 439:56-60, 2005

37. Sorensen P: Spinal epidural abscesses; conservative treatment for selected subgroups of patients. Br J Neurosurg 17:513-518, 2003

38. Tang HJ, Lin HJ, Liu YC, Li CM: Spinal epidural abscess-experience with 46 patients and evaluation of prognostic factors. J Infect 45: 76-81, 2002

39. Turgut M: Complete recovery of acut paraplegia due to pyogenic thoracic spondylodiscitis with an epidural abscess. Acta Neurochir (Wien)150:381-386, 2008
40. Vilke GM, Honingford EA: Cervical spine epidural abscess in a patient with no redisposing risk factors. Ann Emerg Med 27: 777-780, 1996

41. Wiley AM, Trueta J: The vascular anatomy of the spine and its relationship to pyogenic vertebral osteomyelitis. J Bone Joint Surg Br 41:796-809, 1957

42. Yang SY. Spinal epidural abscess. NZ Med J 95: 302-304, 1982

43. Zeidman S, Ducker T. Infectious complications of spine surgery techniques. Complication avoidance and management. Philedelphia: Churchill Livingstone, 1999:1145-1157 